\title{
CHOROBA SYMULATOROWA
}

\section{W SZKOLENIU PILOTÓW WOJSKOWYCH I CYWILNYCH RÓŻNYCH TYPÓW STATKÓW POWIETRZNYCH}

\author{
SIMULATOR SICKNESS IN THE AIRCRAFT TRAINING OF MILITARY \\ AND CIVIL PILOTS OF VARIOUS TYPES OF AIRCRAFT \\ Przemysław Wojciechowski ${ }^{1}$, Jan Błaszczyk ${ }^{2}$ \\ ${ }^{1} 31$ Baza Lotnictwa Taktycznego / 31st Tactical Air Base, Poznań, Poland \\ ${ }^{2}$ Uniwersytet Medyczny w Łodzi / Medical University of Lodz, Łódź, Poland \\ Katedra Nauk Podstawowych, Zakład Fizjologii Człowieka / Chair of Basic Science, Department of Human Physiology
}

\begin{abstract}
STRESZCZENIE
Wstęp: Wraz z większą popularnością i dostępnością szkoleń symulatorowych wykorzystywanych do treningu pilotów zaobserwowano pojawianie się licznych efektów ubocznych tej technologii. Objawy choroby symulatorowej są zbliżone do dolegliwości związanych z chorobą lokomocyjną - m.in. zawroty głowy, wymioty, a także dezorientacja przestrzenna oraz ograniczenie zdolności koncentracji. Zależą one jednak od indywidualnych predyspozycji użytkowników symulatorów. Materiał i metody: Celem pracy była ocena prawdopodobieństwa wystąpienia choroby symulatorowej podczas ćwiczeń w wirtualnej rzeczywistości oraz jej wpływu na efektywność szkolenia. Próba badawcza liczyła 32 wojskowych i 16 cywilnych pilotów różnych typów statków powietrznych. W celu subiektywnej oceny stanu psychofizycznego pilotów wykorzystano ankietę wzorowaną na Simulator Sickness Questionnaire (SSQ). Wyniki: Wyodrębniono 4 główne czynniki wpływające na możliwość wystąpienia choroby symulatorowej: wiek badanej osoby, zróżnicowanie misji, rodzaj statku powietrznego i podatność na chorobę lokomocyjną. Wnioski: W związku $\mathrm{z}$ indywidualnymi predyspozycjami badanych pilotów określenie ryzyka wystąpienia choroby symulatorowej wydaje się trudne. Istnieją jednak czynniki, które zwiększają prawdopodobieństwo zachorowania - przeziębienie, spożywane leki, niedobór snu i ogólne zmęczenie. Niepokojący jest brak wiedzy na temat choroby symulatorowej wśród pilotów. Warto zatem zastanowić się nad możliwościami edukacji tej grupy zawodowej w tym zakresie, przede wszystkim w celu uzyskiwania lepszych wyników w sesjach symulatorowych, w sytuacji łatwego dostępu do wirtualnej rzeczywistości. Med. Pr. 2019;70(3):317-325
\end{abstract}

Słowa kluczowe: choroba symulatorowa, rzeczywistość wirtualna, pilot, badanie ankietowe, symulatory, kwestionariusz SSQ

\begin{abstract}
Background: With the rise in popularity and availability of simulators for the aircraft training of pilots, numerous side effects of that technology have been noted among their users. The symptoms of simulator sickness are similar to the symptoms of motion sickness. Dizziness, nausea, as well as spatial disorientation and a limited capacity for concentration may be observed. However, those symptoms depend on individual user's predispositions. Material and Methods: The aim of the research was to assess the probability of occurrence of simulator sickness during exercises in virtual reality, and its impact on the effectiveness of training. Thirty two military and 16 civilian pilots of various types of aircraft took part in the research. For the subjective assessment of the psychophysical condition of the pilots, a questionnaire based on Simulator Sickness Questionnaire (SSQ) was used. Results: Four main factors that are associated with the prevalence of simulator sickness have been identified, i.e., age, a variety of missions, a type of aircraft and susceptibility to motion sickness. Conclusions: Due to the individual characteristics of each person, determining the risk of occurrence of simulator sickness seems to be difficult. However, there are some factors that increase the probability of getting sick, including cold, medications, lack of sleep and general fatigue. The lack of knowledge about simulator sickness among aircraft pilots appears rather alarming. When access to virtual reality is so wide, the possible ways of expanding the knowledge in this area should be considered, especially in order to obtain better results in simulator sessions. Med Pr. 2019;70(3):317-25
\end{abstract}

Key words: simulator sickness, virtual reality, pilot, questionnaire survey, simulators, Simulator Sickness Questionnaire

Autor do korespondencji / Corresponding author: Przemysław Wojciechowski, 31 Baza Lotnictwa Taktycznego, ul. Silniki 1,61-325 Poznań, e-mail: przemyslaw.a.wojciechowski@gmail.com Nadesłano: 26 marca 2018, zatwierdzono: 6 grudnia 2018 


\section{WSTĘP}

W przeciągu ostatnich 20 lat można zauważyć znaczący wzrost zastosowania symulatorów w różnych dziedzinach życia. Obecnie oprócz symulatorów do szkolenia pilotów statków powietrznych, kierowców pojazdów transportowych (ciężarówek, wózków widłowych itd.) czy nauki żeglugi stosuje się również symulatory rozrywkowe (VR headsets) dostępne dla szerokiego grona odbiorców. Wraz ze wzrostem popularności i dostępności symulatorów, a także ze zwiększeniem ich wykorzystania, zauważono występowanie skutków ubocznych tej technologii. Informacje na ten temat pochodzą głównie z instytutów i ośrodków szkoleniowych wyposażonych w pełne symulatory lotu (full flight simulator FFS), czyli modele najbardziej zaawansowane technicznie. Mają one w pełni funkcjonalną i pełnowymiarową replikę kokpitu oraz system wizualizacji zapewniający płynny widok o wysokiej rozdzielczości, obrazujący sytuację przestrzenną poza kabiną. Należy zaznaczyć, że choroba symulatorowa występuje u pilotów w symulatorach zarówno opartych na systemie projekcyjnym (spatially immersive display - SID), jak i wykorzystujących infohełm (head-mounted display - HMD) [1,2].

Choroba symulatorowa objawia się dolegliwościami takimi jak nudności, zawroty głowy, senność, oszołomienie, zmęczenie, bladość skóry, zimne poty, wymioty, ból głowy, trudności ze skupieniem czy zmęczenie oczu. W badaniach [3] odnotowano także występowanie halucynacji, ale jest to sytuacja bardzo rzadka. Dolegliwości w chorobie symulatorowej pokrywają się z objawami choroby lokomocyjnej czy morskiej [4]. Należy jednak zaznaczyć, że główne symptomy chorób związanych z ruchem mają zasadniczo podłoże gastryczne (wymioty, nudności, odbijanie się), podczas gdy w chorobach powodowanych kontaktem $\mathrm{z}$ wirtualną rzeczywistością występują dolegliwości ze strony narządu wzroku (trudności skupienia wzroku, ból głowy, rozmazany obraz) $[1,2,5]$.

W literaturze można znaleźć dane dotyczące czynników sprzyjających występowaniu choroby symulatorowej. Płeć, podatność na chorobę lokomocyjną, różne profile misji wykonywanych podczas ćwiczeń oraz wiek mogą determinować odczuwanie dolegliwości. Ponadto czynnikami zwiększającymi podatność na chorobę są: deficyty snu, grypa, choroby górnych dróg oddechowych, zapalenie uszu, niektóre leki, rozstrój żołądka, przeziębienie, kac, silny stres $[1,2,4-6]$.

Chorobą symulatorową nazywamy stan zbliżony do choroby lokomocyjnej, przy czym zasadniczą różnicą jest mechanizm ich powstawania. Główną okolicznością wywołującą chorobę lokomocyjną jest ruch, czyli wystawienie organizmu na rzeczywiste bodźce, natomiast $\mathrm{w}$ chorobie symulatorowej mamy do czynienia $\mathrm{z}$ iluzją ruchu (vection). W dotychczasowych badaniach nie udało się jednoznacznie określić przyczyn występowania choroby symulatorowej. Wynika to ze złożonego charakteru bodźców. Najpowszechniejszą teorią jest, że podczas korzystania $\mathrm{z}$ symulatora informacje przekazywane do ośrodkowego układu nerwowego przez błędniki, narząd wzroku i proprioreceptory są niezgodne ze statycznością symulatora i świadomością bezruchu u użytkownika. Stan ten wywołuje konflikt przedsionkowo-wzrokowy, a w rezultacie - zespół symptomów określanych mianem choroby symulatorowej $[1,2,6]$.

Celem badań była ocena prawdopodobieństwa wystąpienia choroby symulatorowej podczas ćwiczeń w wirtualnej rzeczywistości oraz ocena wpływu niepożądanych objawów na efektywność szkolenia, jak również sprawdzenie, czy w środowisku pilotów wojskowych, w którym ćwiczenia są bardziej wymagające, choroba symulatorowa występuje równie często jak w środowisku pilotów cywilnych.

\section{MATERIA I I METODY}

W badaniu wzięło udział 48 pilotów różnych typów statków powietrznych. W czasie wykonywania zadań na symulatorach wszyscy posiadali ważne orzeczenia lotniczo-lekarskie, poświadczające brak przeciwwskazań do wykonywania samodzielnych lotów. Żaden z pilotów przed sesją symulatorową nie skarżył się na zły stan psychofizyczny. Średnia wieku mieściła się w przedziale 30-35 lat, przy czym najmłodszy $\mathrm{z}$ badanych miał $<25$ lat, a najstarszy $->45$ lat. Trzydziestu dwóch pilotów spośród biorących udział w badaniu na co dzień kieruje wojskowymi statkami powietrznymi.

Ankietowani byli pilotami 4 typów statków powietrznych. Wśród nich znajdowało się:

17 pilotów śmigłowców (wojskowych),

15 pilotów samolotów wysokomanewrowych (wojskowych),

13 pilotów samolotów pasażerskich (cywilnych),

3 pilotów samolotów ultralekkich (cywilnych).

Zestawienie rodzajów statków powietrznych i wieku pilotów biorących udział w badaniu zostało przedstawione w tabeli 1 .

Spośród biorących udział w badaniu 22 osoby (45\%) można uznać za doświadczone, gdyż odbyły powyżej 1000 godz. lotów w powietrzu. Najbardziej doświadczo- 
Tabela 1. Wiek badanych i rodzaje pilotowanych statków powietrznych

Table 1. Respondents' age and the type of aircrafts

\begin{tabular}{|c|c|c|c|c|}
\hline $\begin{array}{c}\text { Wiek } \\
\text { [w latach] } \\
\text { Age } \\
\text { [years] }\end{array}$ & \multicolumn{4}{|c|}{$\begin{array}{l}\text { Piloci } \\
\text { Pilots } \\
\text { [n] }\end{array}$} \\
\hline$<25$ & 11 & 0 & 5 & 0 \\
\hline $30-35$ & 0 & 6 & 2 & 2 \\
\hline $35-40$ & 1 & 5 & 1 & 0 \\
\hline $40-45$ & 1 & 5 & 0 & 0 \\
\hline $45>$ & 0 & 1 & 2 & 0 \\
\hline
\end{tabular}

Tabela 2. Rodzaje statków powietrznych i średnia liczby godzin ćwiczeń wykonanych przez pilotów biorących udział w badaniu Table 2. The type of aircraft and the average number of hours of exercises performed by the pilots participating in the research

\begin{tabular}{|c|c|c|c|c|}
\hline \multirow{3}{*}{$\begin{array}{c}\text { Rodzaj statku powietrznego } \\
\text { Type of aircraft }\end{array}$} & \multicolumn{4}{|c|}{$\begin{array}{c}\text { Nalot } \\
\text { [godz.] } \\
\text { Total documented flight time } \\
{[\mathrm{h}]}\end{array}$} \\
\hline & \multicolumn{2}{|c|}{$\begin{array}{l}\text { symulator } \\
\text { simulator }\end{array}$} & \multicolumn{2}{|c|}{$\begin{array}{l}\text { powietrze } \\
\text { air }\end{array}$} \\
\hline & $\begin{array}{c}\min .- \text { maks. } \\
\min .-\max \end{array}$ & $\mathrm{M} \pm \mathrm{SD}$ & $\begin{array}{l}\min .- \text { maks. } \\
\min .-\max \end{array}$ & $\mathrm{M} \pm \mathrm{SD}$ \\
\hline $\begin{array}{l}\text { Samolot wysokomanewrowy / High } \\
\text { maneuverability aircraft }\end{array}$ & $100-460$ & $245 \pm 105$ & $350-1200$ & $637 \pm 266$ \\
\hline Śmigłowiec / Helicopter & $50-500$ & $196 \pm 105$ & $20-4500$ & $1845 \pm 266$ \\
\hline Pasażerski / Airliner & $44-500$ & $185 \pm 138$ & $220-14000$ & $2826 \pm 4495$ \\
\hline Ultralekki / Ultralight aircraft & $5-60$ & $32 \pm 28$ & $65-440$ & $235 \pm 190$ \\
\hline
\end{tabular}

ny pilot przebywał w powietrzu 14000 godz., a pilot o najmniejszym doświadczeniu - 20 godz. Piętnastu ankietowanych (31\%) spędziło ponad 200 godz. za sterami symulatora. Najmniejsza deklarowana liczba godzin spędzona w symulatorze wynosiła 5 , a największa - 500 . Przed badaniem 37 pilotów (77\%) nie znało pojęcia choroby symulatorowej.

Zestawienie rodzajów statków powietrznych i średniej liczby godzin ćwiczeń na symulatorach wykonanych przez pilotów zostało przedstawione w tabeli 2.

\section{Metody}

Chcąc ocenić prawdopodobieństwo wystąpienia choroby symulatorowej w czasie wykonywania ćwiczeń w rzeczywistości wirtualnej, wszystkich pilotów poproszono o wypełnienie ankiet, które zostały przygotowane w oparciu o Simulator Sickness Questionnaire (SSQ) [7] (załącznik 1). Ankiety były wypełniane po szkoleniach, podczas których wykorzystano symulatory. W związku z symulowaniem lotów różnymi typami statków powietrznych czas trwania poszczególnych sesji symulatorowych był zróżnicowany.

Symulatory projekcyjne wykorzystane podczas badań posiadały w pełni funkcjonalną i pełnowymiarową replikę kokpitu oraz system wizualizacji zapewniający płynny widok o wysokiej rozdzielczości, obrazujący sytuację przestrzenną poza kabiną.

Podczas sesji piloci „latali” w zróżnicowanych warunkach atmosferycznych, a profil ich misji był zależny od rodzaju statków powietrznych, których lot był symulowany. Zadania pilotów wojskowych polegały głównie na przechwytywaniu celów, wykonywaniu skomplikowanych manewrów oraz doskonaleniu zachowań w sytuacjach awaryjnych, natomiast piloci cywilni wykony- 


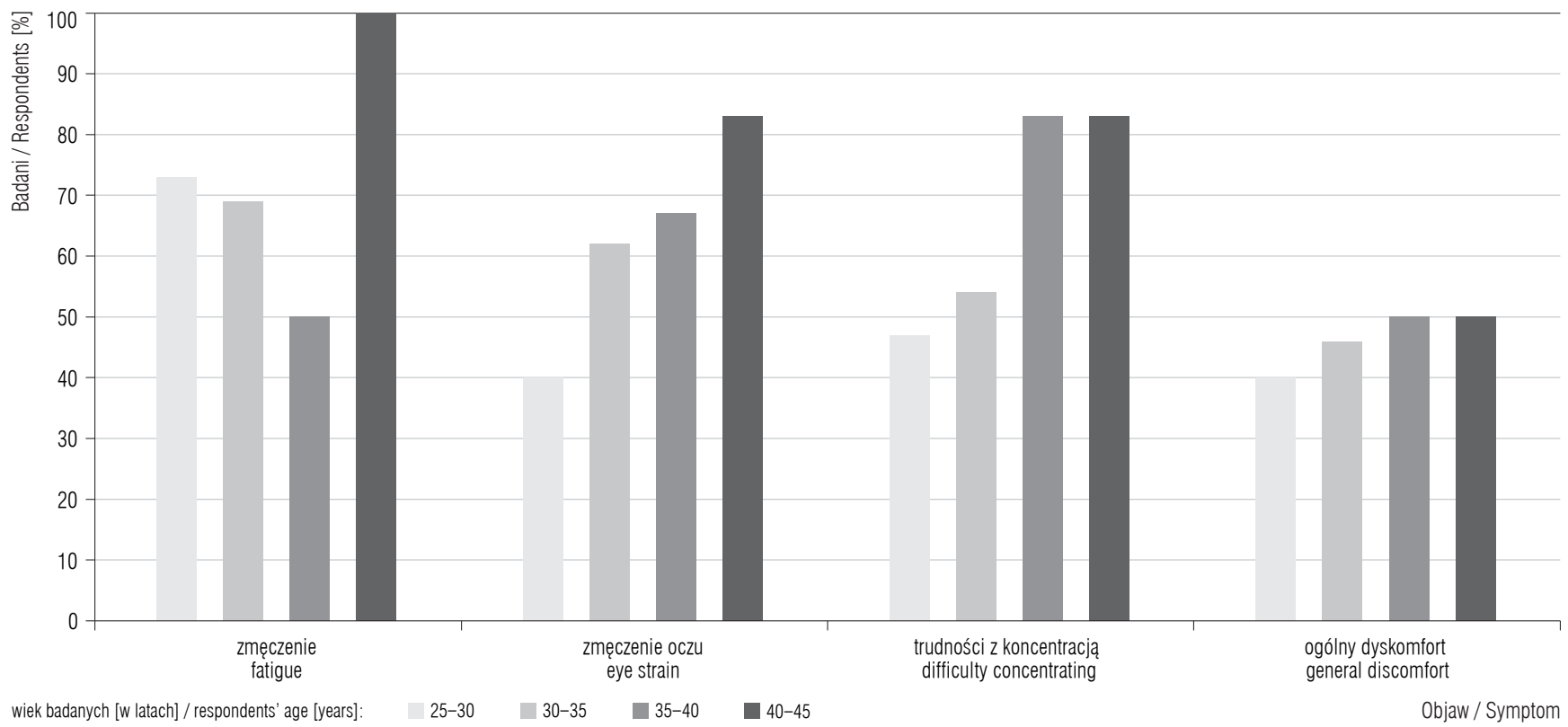

Rycina 1. Objawy zgłaszane przez badanych podczas ćwiczeń na symulatorach Figure 1. The symtoms reported by the respondents during simulator exercises

wali przede wszystkim loty w warunkach ograniczonej widoczności (na podstawie wskazań przyrządów pokładowych), treningi podchodzenia do lądowania, jak również ćwiczenia zachowań w sytuacjach awaryjnych.

\section{WYNIKI}

Podczas badania wyodrębniono poszczególne cechy charakterystyczne, według których skategoryzowano zebrane dane.

\section{Wiek}

Podobnie jak w przypadku choroby lokomocyjnej, wraz z wiekiem zwiększa się przystosowanie organizmu do oddziaływania wirtualnej rzeczywistości. Johnson [3] w swojej pracy zauważył, że w wieku 2-12 lat podatność na negatywne efekty wirtualnej rzeczywistości jest największa, następnie znacząco maleje ona w przedziale do 21 r.ż. Powyżej tego wieku spadek podatności jest już mniejszy. U osób, które przekroczyły 50 r.ż., występowanie choroby symulatorowej jest niezwykle rzadkie [3].

Autorzy niniejszego artykułu podczas badania również ustalili, że wraz z wiekiem pilota zmniejsza się jego podatność na chorobę symulatorową. Biorąc pod uwage całą grupę respondentów, niezależnie od typu pilotowanego statku powietrznego, wysoki odsetek zmęczenia (73\%) zaobserwowano u badanych w wieku 25-30 lat, następnie procent ten malał aż do wartości $69 \%$ dla przedziału 30-35 lat i do 50\% - dla 35-40 lat. Aberrację można zauważyć w przedziale 40-45 lat, gdyż wszyscy piloci w tej grupie wiekowej zgłaszali zmęczenie po sesjach symulatorowych.

Należy zwrócić uwagę, że dolegliwości takie jak zmęczenie oczu, trudności z koncentracją i ogólny dyskomfort wraz z wiekiem występowały częściej - przedstawiono to na rycinie 1 .

\section{Zróżnicowane misje}

Nie jest zaskoczeniem, że wraz ze wzrostem prędkości, zwiększeniem liczby manewrów czy lotami na niskiej wysokości obserwuje się zwiększenie podatności pilota na chorobę symulatorową. Ze względu na duże nagromadzenie bodźców wzrokowych, które muszą przetworzyć piloci wojskowych statków powietrznych, główne symptomy choroby to: zmęczenie oczu, trudności skupienia, zamazany obraz i utrata orientacji. W literaturze $[8,9]$ zwraca się uwagę na wyraźną korelację pomiędzy wzrostem pobudzenia obszarów mózgu odpowiedzialnych za wzrok a odczuciem dyskomfortu u pilota, np. bólem głowy.

Piloci cywilni odczuwali negatywne skutki choroby w mniejszym stopniu, ponieważ ich profil lotu był spokojniejszy, wykonywany z mniejszymi prędkościami i w większej odległości od ziemi, przez co więcej informacji otrzymywali z przyrządów pomiarowych znajdujących się w kokpicie niż z systemu wizualizacji sytuacji przestrzennej.

Porównanie występowania objawów choroby symulatorowej podczas symulowania lotów wojskowych i cy- 
Tabela 3. Objawy zgłaszane przez badanych podczas ćwiczeń na symulatorach statków powietrznych wojskowych i cywilnych Table 3. The symptoms reported by the respondents during simulator exercises on military and civilian aircraft

\begin{tabular}{lcc}
\hline \multicolumn{1}{c}{$\begin{array}{c}\text { Objaw } \\
\text { Symptom }\end{array}$} & \multicolumn{2}{c}{$\begin{array}{c}\text { Badani } \\
\text { Respondents } \\
{[\%]}\end{array}$} \\
\cline { 2 - 3 } & $\begin{array}{c}\text { symulator samolotu wojksowego } \\
\text { military aircraft simulator }\end{array}$ & $\begin{array}{c}\text { symulator samolotu cywilnego } \\
\text { civilian aircraft simulator }\end{array}$ \\
\hline $\begin{array}{l}\text { Zmęczenie oczu / Eye strain } \\
\text { Trudności ze skupieniem się / Difficulty } \\
\text { concentrating }\end{array}$ & 65 & 44 \\
Zamazany obraz / Blurred vision & 59 & 38 \\
Utrata orientacji / Loss of orientation & 38 & 6 \\
\hline
\end{tabular}

Tabela 4. Objawy zgłaszane przez badanych podczas ćwiczeń na symulatorach samolotu bojowego F16, śmigłowca, samolotu pasażerskiego i ultralekkiego

Table 4. The symptoms reported by the respondents during simulator exercises on F16 aircraft, helicopters, airliners and ultralight aircraft

\begin{tabular}{|c|c|c|c|c|}
\hline $\begin{array}{l}\text { Objaw } \\
\text { Symptom }\end{array}$ & \multicolumn{4}{|c|}{$\begin{array}{c}\text { Badani } \\
\text { Respondents } \\
{[\%]}\end{array}$} \\
\hline Zmęczenie / Fatigue & 87 & 53 & 62 & 100 \\
\hline Zmęczenie oczu / Eye strain & 67 & 65 & 23 & 100 \\
\hline $\begin{array}{l}\text { Trudności ze skupieniem się / Difficulty } \\
\text { concentrating }\end{array}$ & 67 & 53 & 23 & 100 \\
\hline Ogólny dyskomfort / General discomfort & 40 & 41 & 23 & 100 \\
\hline
\end{tabular}

wilnych statków powietrznych zostało przedstawione w tabeli 3 .

Istotne znaczenie ma również czas trwania 1 sesji symulatorowej. W przypadku gdy trening trwał dłużej niż 60 min, aż $85 \%$ badanych - niezależnie od tego, jakiego statku powietrznego lot był symulowany - odczuwało większe zmęczenie, podczas gdy w sesjach trwających poniżej 1 godz. taką dolegliwość odczuło tylko 33\% respondentów.

\section{Rodzaj statku powietrznego}

W literaturze [10] omawia się wyniki badań, według których najwięcej symptomów choroby symulatorowej występuje u pilotów śmigłowców. Jest to prawdopodobnie spowodowane lotami na niskich wysokościach $\mathrm{z}$ widokiem na zmieniające się podłoże. Autorzy niniejszego artykułu nie mogą potwierdzić takich danych, $\mathrm{z}$ ich badań wynika bowiem, że piloci śmigłowców i samolotów F16 doświadczyli choroby symulatorowej w podobnym stopniu; można nawet stwierdzić, że to piloci samolotów wysokomanewrowych bardziej odczuli jej skutki. Negatywny wpływ na stan psychofizyczny w największym stopniu dotyczył pilotów samolotów ultralekkich. Najmniej dolegliwości wydaje się wywoływać symulator samolotów pasażerskich. W tabeli 4 zestawiono objawy choroby podczas ćwiczeń na symulatorach: samolotu bojowego F16, śmigłowca, samolotu pasażerskiego i ultralekkiego.

Pomimo rygorystycznych badań dopuszczających do lotu oraz wymagających ćwiczeń adaptacyjnych największe nasilenie symptomów choroby symulatorowej można zauważyć u pilotów wysokomanewrowych statków powietrznych i śmigłowców - choć są to w większości przypadków objawy określane jako rzad- 


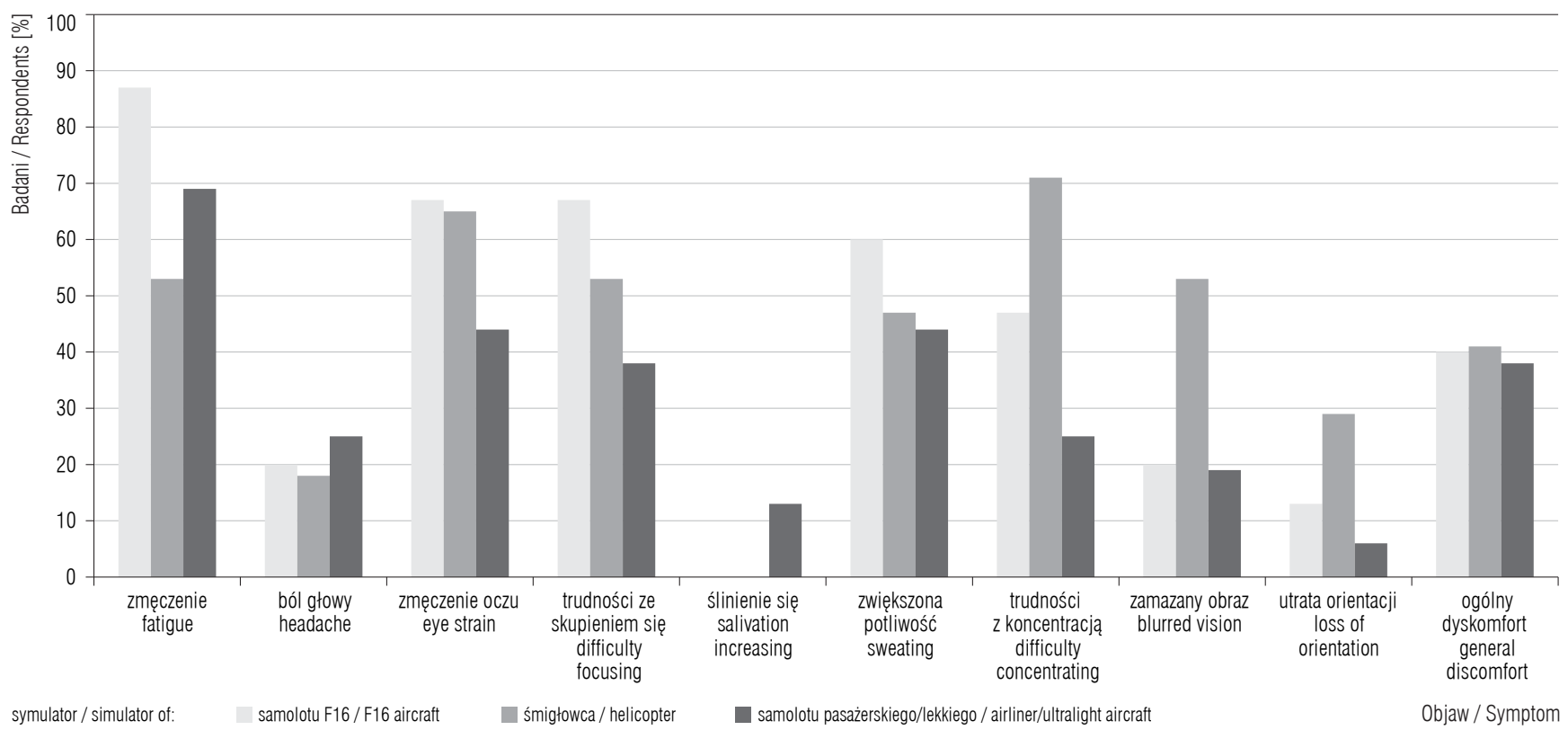

Rycina 2. Objawy u badanych w zależności od rodzaju symulowanego statku powietrznego

Figure 2. Respondents' symptoms depending on types of aircraft simulators

ko występujące. Procentowe zestawienie symptomów $\mathrm{w}$ zależności od symulowanego statku powietrznego przedstawiono na rycinie 2. Uwzględnione zostały wyniki badań dotyczące wszystkich 4 grup pilotów, jednak pilotów samolotów pasażerskich i maszyn ultralekkich połączono w jedną grupę $\mathrm{z}$ uwagi na podobieństwo wykonywanych ćwiczeń/manewrów.

\section{Podatność na chorobę lokomocyjną}

Zauważono, że osoby, które są podatne na chorobę morską czy lokomocyjną, z dużym prawdopodobieństwem zachorują również na chorobę symulatorową. Wystąpienie objawów podczas jednej sesji w wirtualnej rzeczywistości predysponuje daną osobę do ponownego odczuwania dolegliwości w czasie następnych ćwiczeń [3].

\section{OMÓWIENIE}

Symulatory są ważną częścią szkolenia lotniczego. Umożliwiają doskonalenie umiejętności w warunkach niesprzyjającej pogody, pozorują niebezpieczne sytuacje w przestrzeni, nie narażając ani statków powietrznych, ani zdrowia i życia samych pilotów. Czy choroba symulatorowa wpływa na szkolenie pilotów? Niewątpliwie stanowi ona przeszkodę, ale możliwą do pokonania; jej skutki można co najmniej zminimalizować.

Wystąpienie objawów, które byłyby wskazaniem do zakończenia treningu, zdarza się niezwykle rzadko.
Wszystkie osoby biorące udział w badaniu ukończyły swoją sesję. Negatywny wpływ choroby symulatorowej na efektywność szkolenia lotniczego nie jest więc duży. Biorąc pod uwagę zalety - bezpieczeństwo pilota i maszyny, redukcję kosztów, trening wielu wersji zdarzeń, oraz to, że ewentualne niedogodności nie zagrażają trwale zdrowiu, można stwierdzić, że szkolenie symulatorowe jest potrzebne i jak na razie niezastąpione. Oczywiście należy się zastanowić, czy obecnie, przy tak powszechnym dostępie do wirtualnej rzeczywistości, wobec zwiększonej liczby użytkowników nie pojawią się kolejne, poważniejsze objawy choroby symulatorowej.

Ocena procesów zachodzących w organizmie podczas konfliktu przedsionkowo-wzrokowego jest niezwykle złożona i zależy od indywidualnych predyspozycji użytkowników symulatorów. Ponadto oszacowanie możliwości wystąpienia choroby symulatorowej u pilotów cywilnych i wojskowych nie jest proste. Wpływa na to szereg czynników. Od pilotów wojskowych wymaga się większej odporności na sytuacje stresogenne, pracy w każdych warunkach pogodowych, ale również wykonywania lotów na małej wysokości przy dużych prędkościach, co sprzyja występowaniu objawów choroby. Piloci cywilni ćwiczą loty z punktu A do punktu B bez zbędnego manewrowania, przez co ich profil lotu jest spokojniejszy, wykonywany przy mniejszej prędkości i większej odległości od ziemi. Otrzymują, jak już podano, więcej informacji z przyrządów pomiarowych znajdujących się w kokpicie niż z systemu wizualizacji sytu- 
Tabela 5. Rodzaje symulowanych statków powietrznych i sesje symulatorowe w roku

Table 5. The types of aircraft and simulator sessions in a year

\begin{tabular}{|c|c|c|}
\hline $\begin{array}{c}\text { Rodzaj statku powietrznego } \\
\text { Type of aircraft }\end{array}$ & \multicolumn{2}{|c|}{$\begin{array}{c}\text { Sesje symulatorowe } \\
\text { Simulator sessions } \\
{[\mathrm{n}]}\end{array}$} \\
\hline $\begin{array}{l}\text { Samolot wysokomanewrowy / High } \\
\text { maneuverability aircraft }\end{array}$ & $60-96$ & $76 \pm 21$ \\
\hline Pasażerski / Airliner & $48-84$ & $52 \pm 23$ \\
\hline Ultralekki / Ultralight aircraft & $24-60$ & $44 \pm 18$ \\
\hline
\end{tabular}

acji przestrzennej. W związku z tym mniejsza była ich podatność na chorobę symulatorową. Co więcej, biorący udział w badaniu piloci samolotów pasażerskich byli najbardziej doświadczoną grupą, co mogło zwiększyć ich odporność na negatywny wpływ rzeczywistości wirtualnej. Choroba symulatorowa pozostaje jednak w dużej mierze indywidualnym odczuciem, nikomu nie udało się więc dotąd udowodnić, że pilot wojskowy będzie ją znosił lepiej niż pilot cywilny i odwrotnie.

W literaturze [11] omawia się badania, według których wraz ze wzrostem nalotu pilotów w warunkach rzeczywistych występuje nasilenie objawów choroby symulatorowej, podczas gdy piloci z małym doświadczeniem są bardziej odporni na jej negatywne skutki. Dodatkowo wysoka rozdzielczość wyświetlaczy i coraz wyższa jakość wykonania symulatorów ułatwia wprowadzenie świadomości pilota $\mathrm{w}$ błąd, że znajduje się on $\mathrm{w}$ rzeczywistym statku powietrznym. Złudzenie to wymusza na organizmie pilota reakcje na bodźce odczuwane każdorazowo podczas lotu (przyspieszenie, zmienność położenia względem ziemi itp.). Autorzy tłumaczą to przyzwyczajaniem się systemu percepcyjnego do warunków, których doświadcza on częściej - czyli towarzyszących lotom rzeczywistym. Z badań przeprowadzonych przez autorów niniejszego artykułu wynika, że piloci wraz z wiekiem oraz doświadczeniem są bardziej odporni na skutki choroby symulatorowej. Zmęczenie odczuwały w największym stopniu osoby w wieku 25-30 lat (73\%), piloci wysokomanewrowych statków powietrznych (aż $87 \%)$ i osoby, które na symulatorach wylatały mniej niż 250 godz. (72\%). We wszystkich wymienionych grupach może być to spowodowane liczbą godzin spędzanych w symulatorach, użytkowanych coraz częściej, jak i zwiększaniem liczby godzin przeznaczonych na trening symulatorowy. Zestawienie rodzajów statków powietrznych i liczby sesji w roku przedstawiono w tabeli 5 .
Według badania autorów niniejszego artykułu małe doświadczenie pilotów samolotów ultralekkich zarówno w lotach symulowanych, jak i rzeczywistych najprawdopodobniej znacząco negatywnie wpłynęło na psychofizyczny stan badanych.

Potwierdziły się również spostrzeżenia z pracy Johnson [3] dotyczące spadku występowania zmęczenia związanego z wyższym wiekiem pilotów. Należy zaznaczyć, że wraz z wiekiem wzrasta doświadczenie i tym można tłumaczyć uodpornienie się na bodźce płynące $\mathrm{z}$ wirtualnej rzeczywistości. Aberracja w grupie wiekowej 40-45 lat może wynikać $\mathrm{z}$ rodzaju statku powietrznego, ponieważ 5 na 6 pilotów z tej grupy wykonywało loty na symulatorach śmigłowców bojowych.

Nasilenie objawów takich jak wymienione wcześniej zmęczenie oczu, trudności z koncentracją oraz ogólnego dyskomfortu prawdopodobnie wynika ze standardowych zmian zachodzących w organizmie wraz $\mathrm{z}$ wiekiem pogorszenia skutecznej koncentracji wzroku przez długi czas i zmniejszonej odporności na niewygodę.

Tak jak w literaturze $[12,13]$, w badaniach autorów niniejszego artykułu również wykazano, że wraz z czasem trwania szkolenia symulatorowego wzrasta nasilenie objawów. W przypadku gdy czas trwania treningu był dłuższy niż $60 \mathrm{~min}$, aż 85\% badanych, niezależnie od typu statku powietrznego, odczuwało zwiększone zmęczenie, podczas gdy w sesjach trwających poniżej 1 godz. podobną dolegliwość odczuło tylko 33\% respondentów. Inne dolegliwości również wyraźnie wzmagały się po 60 min trwania sesji symulatorowej: odsetek pilotów odczuwających trudności ze skupieniem wzroku wzrósł z 20\% do $67 \%$, a ogólny dyskomfort pilotów - z 27\% do 45\%.

Istnieje szereg czynników zwiększających prawdopodobieństwo zachorowania na chorobę symulatorową, m.in. przeziębienie, przyjmowane leki, brak snu oraz ogólnie pojmowane zmęczenie. W literaturze $[8,11,14,15]$ 
opisuje się zasady postępowania $\mathrm{w}$ celu ograniczenia występowania choroby symulatorowej, np.:

1. Loty z użyciem symulatorów nie powinny być planowane w tych samych dniach co szkolenie lotnicze na rzeczywistych statkach powietrznych.

2. Z symulatorów mogą korzystać tylko piloci zdrowi, którzy są w dobrej kondycji psychofizycznej.

3. Osoby niemające wcześniej kontaktu z symulatorem lub po długiej przerwie są w grupie ryzyka wystąpienia choroby.

4. Nie powinno się planować ćwiczeń na symulatorze dłuższych niż 2 godz.

5. Należy robić przerwy.

6. Sesja symulatorowa powinna być tym krótsza, im jest intensywniejsza.

7. Każdorazowo przed zresetowaniem lub zastopowaniem misji pilot powinien zamknąć oczy do czasu ponownego uruchomienia zadania.

8. Po zakończeniu ćwiczenia pilot powinien wysiąść z symulatora dopiero po wyłączeniu wizualizacji przestrzennej i oświetlenia kabiny.

Ponadto w każdym przypadku wystąpienia objawów pilot powinien powiadomić o tym instruktora.

\section{WNIOSKI}

1. Spośród ankietowanych pilotów około $2 / 3$ uległo zmęczeniu, a $1 / 3$ odczuwa zmęczenie podczas sesji symulatorowych częściej niż rzadko.

2. Szczególne nasilenie objawów choroby symulatorowej zaobserwowano wśród pilotów szkolonych na samolotach bojowych.

3. Zastanawiająca i niepokojąca zarazem jest znikoma wiedzy na temat choroby symulatorowej u pilotów, ponieważ aż 37 z 48 badanych nie wiedziało o tej chorobie, a nawet 40 nie potrafiło wskazać symptomów choroby symulatorowej.

4. W związku z coraz większą ekspozycją organizmu człowieka na rzeczywistość wirtualną wydaje się zasadne informowanie ludzi korzystających z symulatorów o występowaniu tej choroby i metodach radzenia sobie $\mathrm{z}$ jej objawami.

\section{PIŚMIENNICTWO}

1. Kluch W:: Badania fizjologiczne przebiegu restytucji narządu przedsionkowego u osób poddawanych przyspieszeniom w symulatorze GYRO IPT. Pol. Przegl. Med. Lotn. 2003;4:399-415

2. Duh H.B., Parker D.E., Philips J.O., Furness T.A.: "Conflicting" motion cues to the visual and vestibular self-motion systems around $0.06 \mathrm{~Hz}$ evoke simulator sickness. Hum. Factors 2004;46(1):142-153, https://doi.org/10.1518/hfes. 46.1.142.30384

3. Johnson D.M.: Introduction to and Review of Simulator Sickness Research. Technical Report 1832. United States Army Research Institute for the Behavioral and Social Sciences, Arlington 2005

4. Gradwell D.P., Rainford D.J.: Ernsting's Aviation and Space Medicine. CRC Press, Boca Raton 2016, ss. 782-783, https://doi.org/10.1201/b13197

5. Stanney K.M., Kennedy R.S., Drexler J.M.: Cybersickness is not simulator sickness. Proc. Hum. Ergon. Soc. Annu. Meet. 1997;41(2):1138-1142, https://doi.org/10.1177/107 118139704100292

6. Biernacki M., Dziuda Ł.: Choroba symulatorowa jako realny problem badań na symulatorach. Med. Pr. 2012; 63(3):377-388

7. Kennedy R.S., Lane N.E., Berbaum K.S., Lilienthal M.G.: Simulator Sickness Questionnaire: An enhanced method for quantifying simulator sickness. Int. J. Aviat. Psychol. 1993;3(3):203-220, https://doi.org/10.1207/s15327108ijap0303_3

8. Bruck S., Watters P.A.: The factor structure of cybersickness. Displays 2011;32(4):153-158, https://doi.org/10.1016/j.displa.2011.07.002

9. Gerwig M., Niehaus L., Kastrup O., Stude P., Diener H.C.: Visual cortex excitability in migraine evaluated by single and paired magnetic stimuli. Headache 2005;45(10):1394-1399, https://doi.org/10.1111/j.1526-4610.2005.00272.x

10. Webb C.M., Bass J.M., Johnson D.M., Kelley A.M., Martin C.R., Wildzunas R.M.: Simulator Sickness in a Helicopter Flight Training School. Aviat. Space Environ. Med. 2009;80(6):541-545, discussion 546, https://doi.org/10.3357/ASEM.2454.2009

11. Virre E., Clark J.B.: Airsickness and Space Sickness. W: Kennedy C.H., Kay G.G. [red.]. Aeromedical Psychology. ASHGATE, Surrey England 2013, ss. 195-213

12. Kennedy R., Stanney K.M., Dunlap W.: Duration and exposure to virtual environments: sickness curves during and across sessions. Presence 2000;9(5):463-472

13. Lackner J.R., Larry R.S.: Motion sickness. W: Squire R. [red.]. Encyclopedia of Neuroscience. Academic Press, Oxford 2009, ss. 989-993

14. Kolasinski E.M.: Simulator Sickness in Virtual Environments. Technical Report 1027. United States Army Research Institute for the Behavioral and Social Sciences, Alexandria 1995

15. Kennedy R.S., Lilienthal M.G., Berbaum K.S., Baltzley D.R., McCauley M.E.: Simulatorsickness in U.S. Navy flight simulators. Aviat. Space Environ. Med. 1989;60(1):10-16 
Załącznik 1. Ankieta użyta w badaniu

Appendix 1. The questionnaire used in the research

\section{ANKIETA}

Szanowni Państwo!

Chciałbym prosić o udział w ankiecie dotyczącej wpływu wirtualnej rzeczywistości na człowieka. Dane, które z niej uzyskam, pozwolą mi w napisaniu pracy dotyczącej odporności na chorobę symulatorową. Ankieta jest anonimowa. Wypełnienie ankiety polega na wybraniu i zaznaczeniu (kółkiem) poprawnych odpowiedzi lub udzieleniu krótkich odpowiedzi. Za wypełnienie ankiety serdecznie dziękuję.

Płeć:

kobieta mężczyzna

Wiek [lat]:$$
\ldots-25
$$

$30-35$

$35-40$

$40-45$

$45-\ldots$

Nalot (w godzinach):

w powietrzu:

na symulatorze:

Częstość ćwiczeń na symulatorze:

$1,2,3,4,5,6,7 /$ tydz. $\quad 5,7,10,15,20 / \mathrm{mc}$

Średnia długość trwania jednej sesji symulatorowej [min]:
$10-20$
$20-40$
$40-60$
$60-\ldots$

Czy słyszał/a Pan/Pani o chorobie symulatorowej?

tak nie

Czy zna Pan/Pani objawy choroby symulatorowej?

tak nie

Jeśli tak, to jakie?

Czy kiedykolwiek, podczas sesji symulatorowej, odczuł/a Pan/Pani:

$\begin{array}{lllll}\text { zmęczenie } & \text { w ogóle } & \text { rzadko } & \text { czasem } & \text { często } \\ \text { ból głowy } & \text { w ogóle } & \text { rzadko } & \text { czasem } & \text { często } \\ \text { zmęczenie oczu } & \text { w ogóle } & \text { rzadko } & \text { czasem } & \text { często } \\ \text { trudności skupienia } & \text { w ogóle } & \text { rzadko } & \text { czasem } & \text { często } \\ \text { nadmierne wydzielanie śliny } & \text { w ogóle } & \text { rzadko } & \text { czasem } & \text { często } \\ \text { pocenie się } & \text { w ogóle } & \text { rzadko } & \text { czasem } & \text { często } \\ \text { mdłości } & \text { w ogóle } & \text { rzadko } & \text { czasem } & \text { często } \\ \text { trudności z koncentracją } & \text { w ogóle } & \text { rzadko } & \text { czasem } & \text { często } \\ \text { zamazany obraz } & \text { w ogóle } & \text { rzadko } & \text { czasem } & \text { często } \\ \text { zawroty głowy } & \text { w ogóle } & \text { rzadko } & \text { czasem } & \text { często } \\ \text { utratę orientacji } & \text { w ogóle } & \text { rzadko } & \text { czasem } & \text { często } \\ \text { „sensacje” żołądkowe } & \text { w ogóle } & \text { rzadko } & \text { czasem } & \text { często } \\ \text { ogólny dyskomfort } & \text { w ogóle } & \text { rzadko } & \text { czasem } & \text { często }\end{array}$

Czy objawy te (jeśli wystąpiły) mogły być spowodowane:

chorobą (przeziębienie, grypa) tak nie

alergią tak nie

zmęczeniem tak nie

przyjmowaniem leków tak nie

kacem tak nie

Na podstawie / Based on: Kennedy R.S. i wsp. / et al.: Simulator Sickness Questionnaire: an enhanced method for quantifying simulator sickness [7].

Ten utwór jest dostępny w modelu open access na licencji Creative Commons Uznanie autorstwa - Użycie niekomercyjne 3.0 Polska / This work is available in Open Access model and licensed under a Creative Commons Attribution-NonCommercial 3.0 Poland License - http://creativecommons.org/ licenses/by-nc/3.0/pl. 